\title{
"Application of decision tree model for prediction of immigration policy in different countries of the world"
}

\begin{tabular}{|c|c|}
\hline AUTHORS & $\begin{array}{l}\text { Viktoriia Apalkova (iD) } \\
\text { Sergiy Tsyganov (D) } \\
\text { Nataliia Meshko (D) } \\
\text { Nadiia Tsyganova (iD } \\
\mathbb{R} \\
\text { Serhii Apalkov (D) }\end{array}$ \\
\hline ARTICLE INFO & $\begin{array}{l}\text { Viktoriia Apalkova, Sergiy Tsyganov, Nataliia Meshko, Nadiia Tsyganova and } \\
\text { Serhii Apalkov (2021). Application of decision tree model for prediction of } \\
\text { immigration policy in different countries of the world. Problems and Perspectives } \\
\text { in Management, 19(3), 513-532. doi:10.21511/ppm.19(3).2021.42 }\end{array}$ \\
\hline DOI & http://dx.doi.org/10.21511/ppm.19(3).2021.42 \\
\hline RELEASED ON & Wednesday, 29 September 2021 \\
\hline RECEIVED ON & Thursday, 15 July 2021 \\
\hline ACCEPTED ON & Monday, 20 September 2021 \\
\hline LICENSE & $\begin{array}{l}(c) E Y \text { EY } \\
\text { This work is licensed under a Creative Commons Attribution } 4.0 \text { International } \\
\text { License }\end{array}$ \\
\hline JOURNAL & "Problems and Perspectives in Management" \\
\hline ISSN PRINT & $1727-7051$ \\
\hline ISSN ONLINE & $1810-5467$ \\
\hline PUBLISHER & LLC “Consulting Publishing Company "Business Perspectives" \\
\hline FOUNDER & LLC "Consulting Publishing Company "Business Perspectives" \\
\hline
\end{tabular}

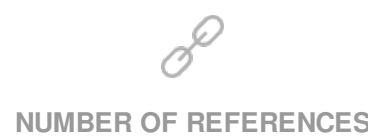

33
NUMBER OF FIGURES

4
NUMBER OF TABLES

2

(C) The author(s) 2021. This publication is an open access article. 


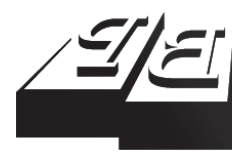

BUSINESS PERSPECTIVES

()

LLC "CPC "Business Perspectives"

Hryhorii Skovoroda lane, 10,

Sumy, 40022, Ukraine

www.businessperspectives.org

Received on: $15^{\text {th }}$ of July, 2021

Accepted on: $20^{\text {th }}$ of September, 2021

Published on: $29^{\text {th }}$ of September, 2021

(C) Viktoriia Apalkova, Sergiy Tsyganov, Nataliia Meshko, Nadiia Tsyganova,

Serhii Apalkov, 2021

Viktoriia Apalkova, Candidate of Economic Sciences, Associate Professor, Faculty of International Economics and Management, Department of International Economics, Kyiv National Economic University named after Vadym Hetman, Ukraine. (Corresponding author)

Sergiy Tsyganov, Doctor of Economic Science, Professor, Department of International Finance of Institute of International Relations, Taras Shevchenko National University of Kyiv, Ukraine.

Nataliia Meshko, Doctor of Economic Science, Professor, Head of Department, Department of Marketing and International Management, Oles Honchar Dnipro National University, Ukraine.

Nadiia Tsyganova, Doctor of Economic Science, Associate Professor, Banking and Insurance Department, Kyiv National Economic University named after Vadym Hetman, Ukraine.

Serhii Apalkov, Candidate of Economic Sciences, Associate Professor, Faculty of International Economics and Management, Department of International Economics. Kyiv National Economic University named after Vadym Hetman, Ukraine.
Viktoriia Apalkova (Ukraine), Sergiy Tsyganov (Ukraine), Nataliia Meshko (Ukraine), Nadiia Tsyganova (Ukraine), Serhii Apalkov (Ukraine)

\section{APPLICATION OF DECISION TREE MODEL FOR PREDICTION OF IMMIGRATION POLICY IN DIFFERENT COUNTRIES OF THE WORLD}

\begin{abstract}
In the past few decades, the ever-increasing dynamics of international migration flows can be observed. At this stage, the governments of major countries in the world are striving to balance the needs of their citizens and the support of immigrants. The paper analyzes factors that affect the immigration policies of various countries and determines the role of ecological factors (such as environmental conditions). The objective of the study is to predict the immigration policies of different countries of the world based on the analysis of the influencing factors, including environmental performance. The research method is based on the use of the RapidMiner software package to build two decision tree models and a static index database of more than 150 countries around the world. The results show that in most cases, the immigration policies of various countries will focus on maintaining the current level of immigration and increasing the number of skilled workers. At the same time, one of the key decision-making factors will be the country's current immigration level, environmental performance, GDP per capita, and the Education index. One of the main conclusions is that the country's environmental indicators have begun to become one of the priority values that determine the state immigration policy. This can be explained by the rising global community interest in the challenges of climate change.
\end{abstract}

\section{Keywords}

immigration policy, skilled workers, climate change, decision tree, immigration, environmental performance

JEL Classification F22, Q56

\section{INTRODUCTION}

At the current stage of increased interaction of national economies, the proliferation of globalization and the tendency for management of international migration flows play an increasing role in public policy. The influence of developed countries on international trends in migration as well as the actions of governments of other countries necessitates the choice of the most optimal strategy for immigration governance.

In this context, it is important to understand that the growth of immigrants in the country has both positive aspects (growth of the consumer market, access to cheap labor, access to new technologies and communications, etc.) and negative (increased pressure on the budget, growth of social conflicts, risks of overpopulation and environmental degradation, etc.).

One of the key functions of countries' immigration policies, as a rule, is called the protection of the internal socio-economic balance through planned control and, if necessary, limiting the access of immigration flows to the country (Timmer \& Williams, 1998; Anderson, 2010). At 
the same time, at this stage of global development, an important key indicator is the environmental performance of the country. The growing problems of climate change and environmental degradation are more and more talked about at international forums and conferences, as well as reports of international institutions (McAuliffe \& Khadria, 2019).

Obviously, the solution must be comprehensive, and since the root of negative environmental changes is human activity, it becomes logical to consider a question of how to minimize this impact and what countries do it in the best way. It is also important to understand the economic model of these countries and their policies for accessing their markets, and not only concerning goods and services, but also the availability of their labor market for immigrants.

\section{LITERATURE REVIEW}

Recently, an increase in interstate migration processes can be observed, leading to increased dynamics of migratory flows. Despite the restrictions on the movement of people between countries related to the fight against coronavirus infection COVID-19, which have been observed over the past 2 years, according to the International Organization for Migration (2019), in 2020, the number of international migrants was 272 million, or $3.5 \%$ of the world population. For comparison, in 2000 these figures were significantly lower: 150 million or $2.8 \%$, respectively. At the same time, countries with a high level of development and income receive more than two-thirds of international migrants.

Labor migration dates to the birth of capitalism and international production, although migration per se has an even longer history. It arose simultaneously with the inception of humankind. The reasons for the constant movement of people in ancient times were hostilities, political conflicts, national and ethnic factors that have existed since the pre-capitalist age. Thus, migration processes have always existed, but only now this movement has such a great impact on the economy, politics, culture, and social component of countries.

The first attempts to explain the factors and analyze the causes that affect migration appeared in the XIX-XX centuries. This process was a consequence of the formation of nation-states and the marking of the borders of countries in which principles of citizenship, people's rights, and freedoms were in process of establishing.

It should be noted that traditionally immigration policy is considered in conjunction with the labor market and the difference in the level of its wages (Dustmann et al., 2005; Cangiano, 2012; Aleksynska \& Tritah, 2015; d'Albis et al., 2018).

For example, Aleksynska and Tritah (2015) described the impact of immigration on the labor market based on the example of European countries. The causal effect of immigration on the employment rate of residents was identified using the instrumental variables strategy based on the historical model. It was found that the employment rate of the country's residents increased in those sectors that accept more immigrants.

Besides, Gabriel and Pellerin (2012) studied the phenomenon of migration and current trends in its modification. The emergence of a migration pattern in which the key factors are migration and its integration into the economies of industrialized countries can be observed. The example of Canada reflects the management of migration flows and the country's policy on immigrants.

Links between temporary immigration to France and the macroeconomic situation of the country have been studied by d'Albis et al. (2018). It was found that immigration flows have a positive effect on GDP per capita in France especially in the case of family immigration but immigration has some negative impact on employment in the country.

As part of a study by the European Policy Center, Ghimis (2016) outlined the migration policy of the European Union. Considering the situation in the labor market and the demographic decline in Europe, the EU should pursue a more ambitious immigration policy to attract labor. 
Lacroix (2012) considered the issue of French migration policy in the context of the problem of balance between national unity and market needs. On the one hand, France as a democratic country promotes equal treatment of foreigners, and on the other, promotes maintenance of the cultural homogeneity of the nation, implying selective immigration that can not fully satisfy the needs of businesses in the labor force.

Détang-Dessendre et al. (2016) also tend to believe that with interregional migration that redistributes labor resources local labor markets become more flexible and unemployment rates fall. The results show that most of the new jobs are occupied by migrants.

Ndiaye (2018) considered the aspect of student migration alongside labor migration. Migration of students is often underestimated and unaccounted for although it meets socially identifiable standards. This kind of migration may turn into long-term or permanent migration and affect the economic performance of the recipient country.

Within this context, the issue of immigrant wages is important, and it has been in the focus of study by Laffineur et al. (2017). Despite such employment trends, the wages of immigrants and residents are quite different. Immigrants' wages increase mainly because immigrants have a wide range of skills, which makes it possible for them to climb the career ladder.

Thus, the gradual increase in the number of international migrants with greater mobility is the subject of many research works at the present stage. The growing importance of migration processes also leads to the study of migration policy by researchers, primarily economists, from developed countries where immigration flows cause many controversial issues (France, Germany, USA, UK, Canada, etc.).

Regarding the impact of environmental factors on international migration, Feng et al. (2010) and Johnson (2011) considered climate change and the negative state of the environment to be the driving force behind migration from Mexico to the United States.
For instance, Feng et al. (2010) quantitatively investigated the relationships between climate variability, crop yields, and population migration responses using the instrumental variables approach. It was emphasized that due to global warming, crop yields in Mexico will significantly decrease (the forecast model was built until 2080). This, in turn, will force many Mexicans to immigrate to the United States. Although the results cannot be mechanically extrapolated to other regions and periods, according to Feng et al. (2010), these findings are important from a global perspective, given that many regions, especially developing countries are expected to significantly decrease crop yields as a result of projected warming.

Another more recent study by Prieur and Schumacher (2016) examines the relationship between immigration policy and climate change through the prism of internal and external conflicts. The main internal conflict is associated with the fact that attracting immigrants for the development of local production leads to a load on infrastructure and accelerates the processes of climate change, as well as causes internal conflicts. In addition, those potential migrants who wish to relocate due to climate change, but who are not allowed to immigrate, can provoke external conflicts. The coexistence of both conflicts makes it difficult to design effective immigration policies. Thus, depending on the parameters, the optimal will be either a steady state without immigration, but with mitigation of environmental impacts, or a steady state with a large number of immigrants, but less mitigation of the negative impact on the environment.

Defining the concept, causes, factors, and patterns of labor migration is a complex process that remains unclear to this day. The reason for this is the rapid development of the world that includes strengthening the social approach of the world economy, democratization of labor relations, internationalization of labor reproduction requirements, standardization of living and working conditions in different parts of the world, personal development, improvement based on universal values, and intensification of globalization processes in the international economy that cause the interdependence of countries and their regional groups. National labor markets are increasingly losing their insularity leading to the formation of a global labor market. 


\subsection{Highlights of relevant recent policies and programs}

It is also worth considering the main trends in immigration policy in developed countries on specific examples. Immigration policy in the United States has undergone significant changes since the beginning of Donald Trump's presidency. The reorganization of the system included measures such as targeted restrictions on legal immigration, the construction of a "wall" on the border with Mexico, and the strict screening of persons allowed to enter. After Joe Biden came to power, there were reversible changes in immigration policy, in particular, the US President lifted restrictions on travel to "predominantly Muslim" countries imposed by the Trump administration, and began other adjustments towards liberalization (Ries, 2020).

The EU's latest immigration policy is based on attracting already qualified migrants. The focus is on improving the EU Blue Card with more flexible entry conditions, attracting innovative entrepreneurs, and developing methods for transparent and easy selection of migrants for relevant employers.

France has been attracting many migrants for a long time although its immigration policy is relatively new. At the current stage, three main trends are identified. First, the length of stay for adaptation has increased in recent years. Secondly, the government's attempts to attract skilled migrants have brought mixed results. On the one hand, the procedure for issuing work visas has become selective and measures have been taken to develop professional mobility, and on the other, such a policy has had a restrictive effect because only a small number of specialists meet the new French market standards. Thirdly, significant efforts have been made for integration at the national level.

The Canadian Express Entry System is designed to attract qualified professionals and facilitate labor immigration. Assessment is based on a scoring system that considers age, education, work experience, desired employment, language skills, and ability to adapt, while omitting criteria of origin, nationality, and religion. Such standards allow determining the potential contribution of a migrant to the national labor force and the welfare of the country.
Thus, in general, the immigration policy of developed countries is quite democratic allowing a significant number of migrants to enter the country. Most developed countries are trying to attract skilled workers as a means of economic development and support for sustainable growth.

\subsection{Future directions of migration processes under the influence of immigration policy of developed countries}

Forecasting future trends is a rather difficult task as migration and international mobility are influenced by several factors. Various reasons besides the migration flow and the emergence of new, flexible types of migration have complicated the conceptualization of the phenomenon. Therefore, it is necessary to dwell more carefully not on the quantitative measurement but the identification of causal relationships and qualitative characteristics of possible results.

Manifestations of the consequences of today's policy can be identified in the future through the development of scenarios, i.e., means of presenting plausible situations with a combination of different variables. Scenarios aim to help in understanding different points of view, opportunities, solutions, and possible failures. They provide an opportunity to look through informational data focusing on structural changes. By combining the results of independent research and work of the International Organization for Migration, the following model can be constructed:

1. The protectionist policy of protecting country's borders from the entry of foreigners may become widespread in the future. Opinions of contemporaries (e.g., Donald Trump) in 20-30 years will become the basis for limiting the mobility of human resources. The United States will come to this need due to the growing illegal migration from Mexico; Europe will not cope with the crisis and will be unable to accept new people. Only a small number of developed countries will allow migrant workers to enter if they pay a certain amount providing them with temporary work and a residence permit. Such a policy will be experimental. The need for low-skilled 
workers among these countries will be minimized due to the high development of technology. Asian countries will attract larger migration flows as their economies will become more attractive to workers. Accordingly, the regulatory policies of Western countries will become less liberal and will focus on domestic needs and national security considering the phenomenon of migration as a threat. Selectivity will culminate when only cost-effective workers will be allowed entry to fill gaps in certain sectors. International management cooperation will decline. In general, there will be a decrease in migration flows.

2. The opposite future is possible under the conditions of support of cooperation, liberalization, and observance of human rights. States will seek to optimize their policies towards openness and successful integration understanding the benefits of migration and its socio-economic contribution to development. Of course, migration will remain a controversial issue that will cause some difficulties in regulation. However, governments will put their efforts to make effective use of the potential for human resource mobility. Immigrants will support stable economic prosperity and make a positive contribution to the host societies. Due to the development of countries and recovery from the crisis, the demand for migrant workers will increase. Better integration will allow workers to be more secure and have a wider range of livelihoods. The value of human capital as a global resource and asset will increase, and more attention will be paid to cooperation and dissemination of information. Economic cooperation will outweigh protectionism facilitating international trade and human mobility. There will be favorable changes in the mood of society that will strive to achieve general well-being. The Canadian scoring system is likely to expand making it easier for migrants to assess their contribution to the economy. In general, migration will be seen as an opportunity to expand one's capacity for countries, get better jobs for migrants, and improve the quality of life for society.

3. The comprehensive impact of technology should not be ruled out. Advances in the fields of computerization and artificial intelligence may push traditional mobility into the background. Today, an increasing number of specialists work remotely via the Internet. Due to the global spread of high technology, there will be no need for physical movement of labor to developed countries. It is possible to create a separate area of immigration policy to manage cyberspace. The network will have its borders, the crossing of which will be regulated by specialists at the behest of the government. The freelance will become the main form of employment facilitating recruitment of required workers and minimizing the legal red tape. Immigration policy will focus on accepting refugees and restricting unregulated migration. The reduction of migration flows will be the result of evolutionary processes in the field of technological support eliminating the need for immigration and easing social tensions (Friedrich-Ebert-Stiftung et al., 2017).

It is impossible to unambiguously determine the future direction of migration. Most developed countries today pursue a policy of open borders and accumulate a significant influx of immigrants. States adopt strategies to help refugees and provide employment for foreign workers. However, any resources are limited. Countries are not able to accept everyone and are forced to use selective mechanisms. Focus on the economic value turns out to be the key criterion now. Some developed countries along with the change of government are moving to the other side of easing legislation. The aim is to protect the interests of the country and national borders that restrict freedom of migration around the world. Therefore, the future dynamics, centers, and features of migration flows directly depend on modern solutions.

The purpose of the paper is to build a predictive model of the immigration policy of states based on the study of various factors of influence. Another important task is to determine the role of environmental factors in the hierarchy of influencing factors.

\section{CONCEPTUAL FRAMEWORK OF THE STUDY}

The classification of immigration policies in practice is expressed in the fact that states at the legal level fix different regimes for the entry of immi- 
grants into their country. One of the most comprehensive and consistent sources of information related to the analysis of international migration and immigration policies is the Population Division of the Department of Economic and Social Affairs at the United Nations. The Division publishes several detailed compilations of world population data, as well as descriptions and analyzes of global demographic trends.

According to the UN (2017) definition, immigration policy is expressed in the policy of the government to influence the level of documented immigration to the country. At the same time, it can be classified into four main categories: 1) Raise - aimed at increasing the level of immigration to the country; 2) Maintain - aimed at keeping the level of immigration at the current level; 3) Lower - aimed at reducing the level of immigration to the country; 4) No interference. There is also a fifth case where the country lacks any policy regarding immigration (Figure 1).

The key difference between the immigration policies of developed countries is their focus on the needs of employers or focus on the skills of immigrants (Stakanov, 2014). Today, labor migration policies in host countries have become more se- lective, with preference given to international migrants with deficient skills. A number of countries are implementing policies to attract or create favorable conditions for such involvement of highly skilled workers. Highly skilled migrants typically receive preferential access conditions and face fewer restrictions than low-skilled migrants in terms of admission conditions, length of stay, job change, and family reunification (Bernardini, 2019).

For analysis, the UN highlights "policy on highly skilled workers" that indicates the Government's policy to influence the level of immigration of highly skilled workers into the country (UN, 2017).

Immigration policy can include various instruments that, depending on the goals, can stimulate the active integration of immigrants into society, and create conditions of strict responsibility for their violation of rules and laws. For example, measures on the integration of immigrants include language skills training, transfer of professional credentials, and protection against discrimination. At the same time, measures on irregular immigration cover penalties for employers of migrants, fines, detention or deportation of migrants, and regularization of legal status under defined schemes or conditions.

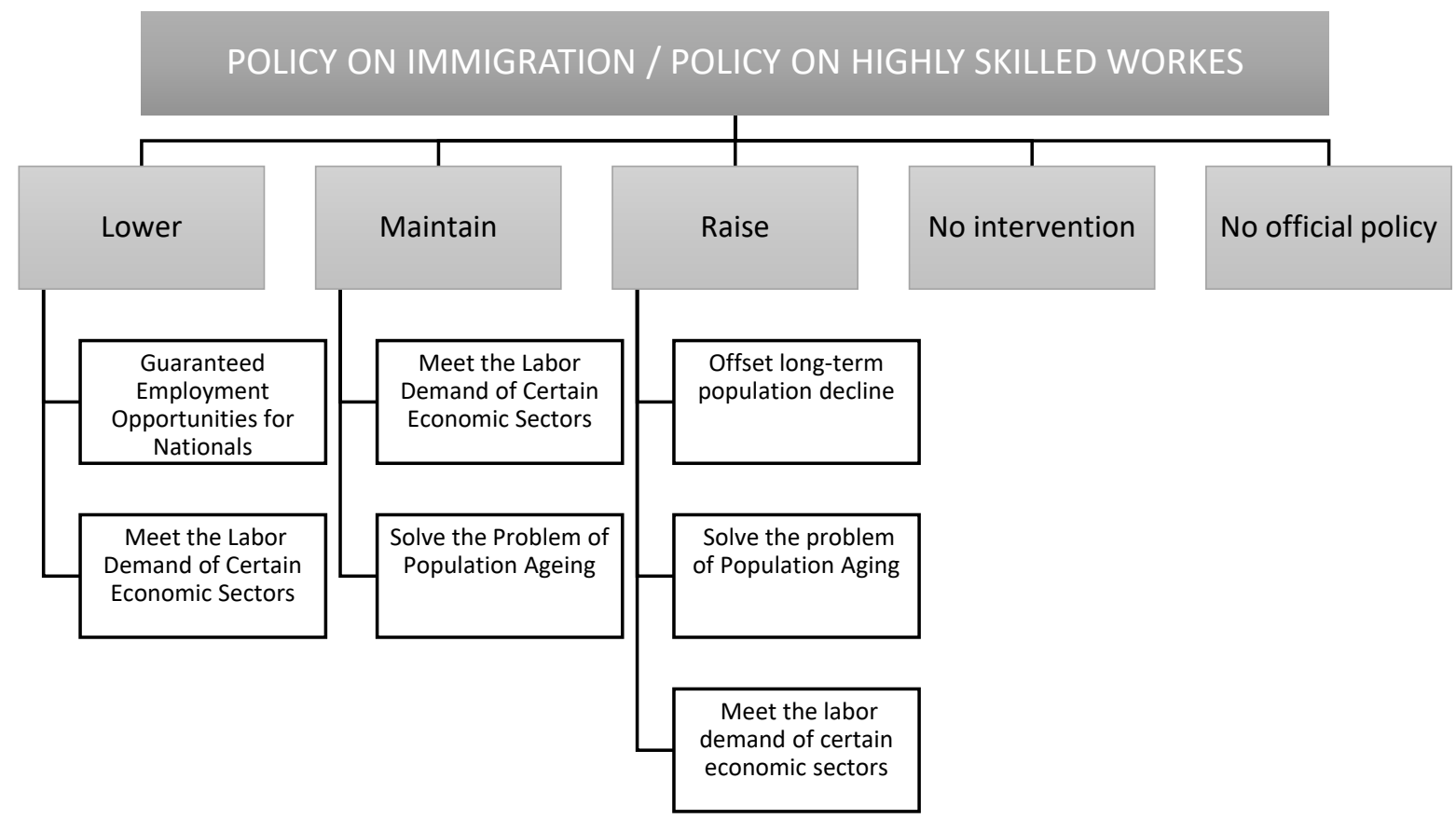

Figure 1. Classification of the main types of immigration policies based on the UN approach 


\section{METHOD}

To analyze the factors affecting the immigration policy of countries, as well as to determine the role of environmental factors, it is proposed to use the decision tree method.

Due to the versatility of the methodological apparatus, the decision tree has industrial applications both in different areas of economic science, which is reflected, for example, in works and other areas of activity, in particular, in information systems and management of technical systems (Patel \& Prajapati, 2018). The possibility of including both qualitative and quantitative information in the decision tree allows analyzing the frequencies of phenomena, events, and objects (including the analysis of the compatibility of the frequencies of different combinations of events).

Thus, the combined application of the decision tree method and associative analysis can reduce the number of calculations by combining them, increase the visibility and interconnection of the results of the analysis of particular problems, and thereby increase business efficiency by increasing the validity and efficiency of management decisions (Chandrasekar et al., 2017).

For the actual calculations, it is planned to use the RapidMiner engine, which offers a variety of op- portunities and integrated environments for data preparation, machine learning algorithms, deep learning, exploration of text, and predictive analytics (Kalra \& Aggarwal, 2017).

The tree consists of leaves and branches. At the root is the most significant factor. All factors are assigned variables called attributes (set of $\mathrm{X}$ attributes). In addition, an important step is the selection of the target label, which is the parameter by which it is expected to predict $Y$. It is planned to build the following two models with data sets represented in the Appendix A:

- $1^{\text {st }}$ model: - will predict what type of immigration policy will be chosen by the state,

- $\quad 2^{\text {nd }}$ model: - will predict which type of policy on highly skilled workers will be selected by the state.

Therefore, the label in the first case will be the type of immigration policy (5 possible values: 1 - Raise, 2 - Maintain, 3 - Lower, 4 - No official policy, 5 No intervention) (Figure 1).

Accordingly, in the second case, the type policy on highly skilled workers will become the label. The value options are the same as in the first case. The operating principle of the decision tree model was formulated by Kalra and Aggarwal (2017). For research purposes, it has been modified by adding

Source: Authors' compilation based on Kalra and Aggarwal (2017).

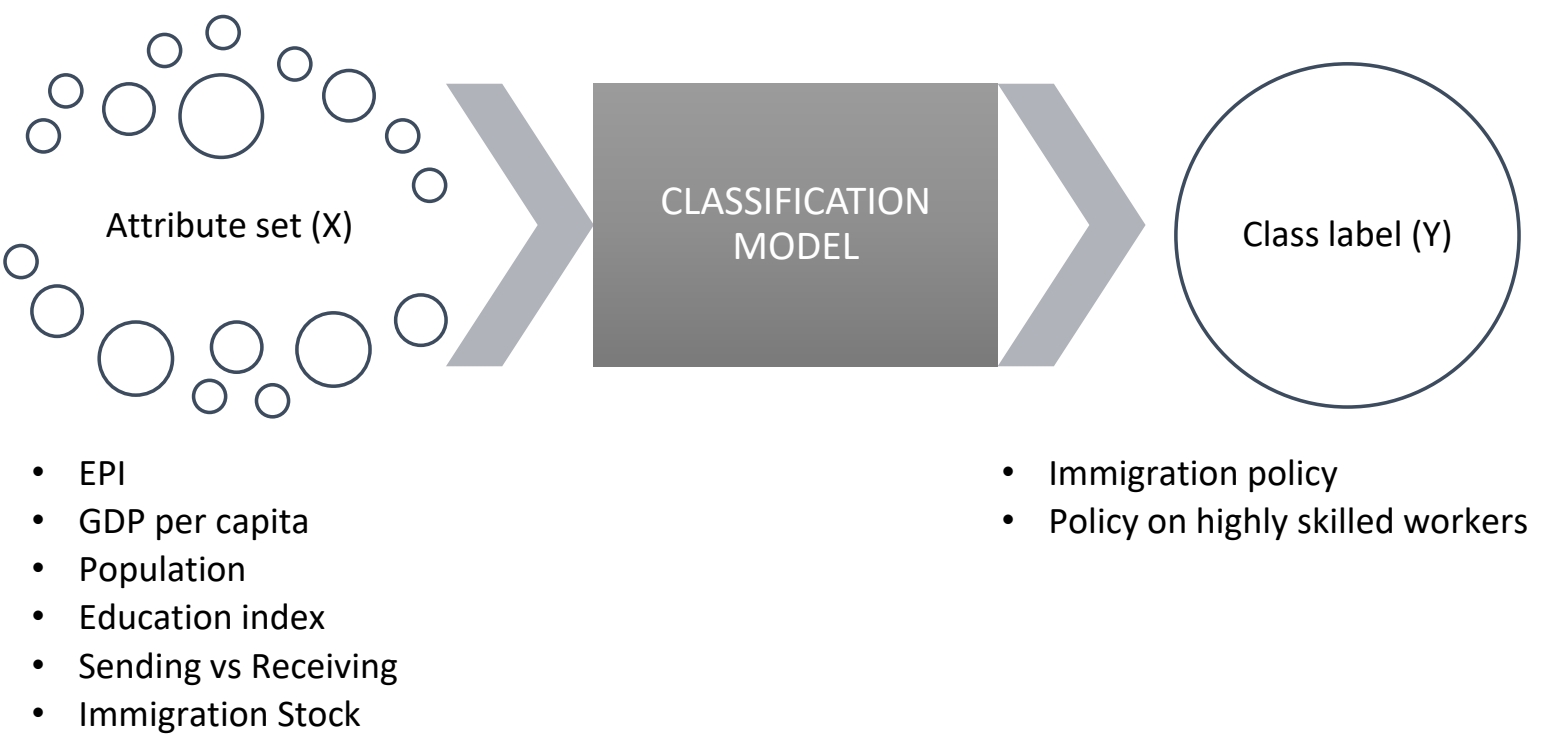

Figure 2. General view of $1^{\text {st }}$ and $2^{\text {nd }}$ classification models 
necessary parameters for attribute set $(\mathrm{X})$ and class label (Y). The results are shown in Figure 2.

The attribute is checked on every internal node, the check result is checked on the branch, and the class label is checked on the leaf node.

As influencing factors, the following indicators have been identified: 1) GDP per capita, 2) population; 3) sending vs receiving ratio, and 4) immigration stock. Two complex indexes have also been added. The first describes the state of the environment in the country - Environmental Performance Index. Using 32 performance indicators across 11 problem categories, the EPI ranks 180 countries for environmental health and ecosystem resilience (Wendling et al., 2020). These indicators make it possible to assess, on a national scale, how close countries are to the established environmental policy goals. EPI offers a scorecard that highlights leaders and laggards in environmental performance and provides actionable guidance for countries as they strive to move towards a sustainable future.

The second comprehensive indicator is the Education index, which is calculated by the UN as a sub-index for the Human Development Index. Education index is a widely accepted measure of educational attainment within a country and is calculated by combining the average years of schooling (of adults) and expected years of schooling (of children), both expressed as an index ob- tained by scaling with the corresponding maxima (Adisa \& McSharry, 2020).

To test the proposed models, relevant analytics for all indicators were collected (Table 1).

\section{RESULTS}

The main tool for analysis and forecasting is the construction of a decision tree using the RapidMiner software package, for which a database of static indicators was collected for more than 150 countries of the world. After calculation, two decision tree models have been built: 1) forecasting immigration policy; 2) forecasting immigration policy for skilled workers.

\subsection{Immigration policy}

To build a decision tree on the Immigration policy, a database was collected according to the indicators indicated in Table 1 for 164 countries of the world. As a result of the calculations, the following conclusions can be drawn. Firstly, in most countries, it is clearly seen that the most significant vector in immigration policy is aimed at maintaining the existing level of immigration (Figure 3 ).

Secondly, the most important among the studied indicators is the EPI indicator. In the countries with the highest EPI, immigration policy is aimed at reducing the number of immigrants. However,

Table 1. Key indicators for calculating the model

\begin{tabular}{|c|c|c|c|c|}
\hline & & & & urce: Authors' compilati \\
\hline Index & Type & Source & $\begin{array}{c}\text { 1st Model } \\
\text { (Immigration } \\
\text { police) }\end{array}$ & $\begin{array}{c}\text { 2nd Model } \\
\text { (Policy on highly } \\
\text { skilled workers) }\end{array}$ \\
\hline Country name (ISO) & Attribute set $(X)$ & United Nations (2017) & + & + \\
\hline Region & Attribute set $(X)$ & United Nations (2017) & + & + \\
\hline Megaregion & Attribute set $(X)$ & United Nations (2017) & + & + \\
\hline $\begin{array}{l}\text { Environmental Performance } \\
\text { Index (EPI) }\end{array}$ & Attribute set $(X)$ & Dahl and Gorodon (2020) & + & + \\
\hline GDP per capita & Attribute set $(X)$ & World Bank Data (n.d.a) & + & + \\
\hline Population & Attribute set $(X)$ & World Bank Data (n.d.b) & + & + \\
\hline Education index & Attribute set $(X)$ & United Nations (2020) & + & + \\
\hline Sending vs Receiving & Attribute set $(X)$ & Migration Policy Institute (n.d.) & + & + \\
\hline Immigration Stock & Attribute set $(X)$ & Migration Policy Institute (n.d.) & + & + \\
\hline Policy on highly skilled workers & Class label (Y) & United Nations (2017) & - & + \\
\hline Policy on immigration & Class label $(Y)$ & United Nations (2017) & + & - \\
\hline Total number of observations (c & ntries) & & 164 & 155 \\
\hline
\end{tabular}




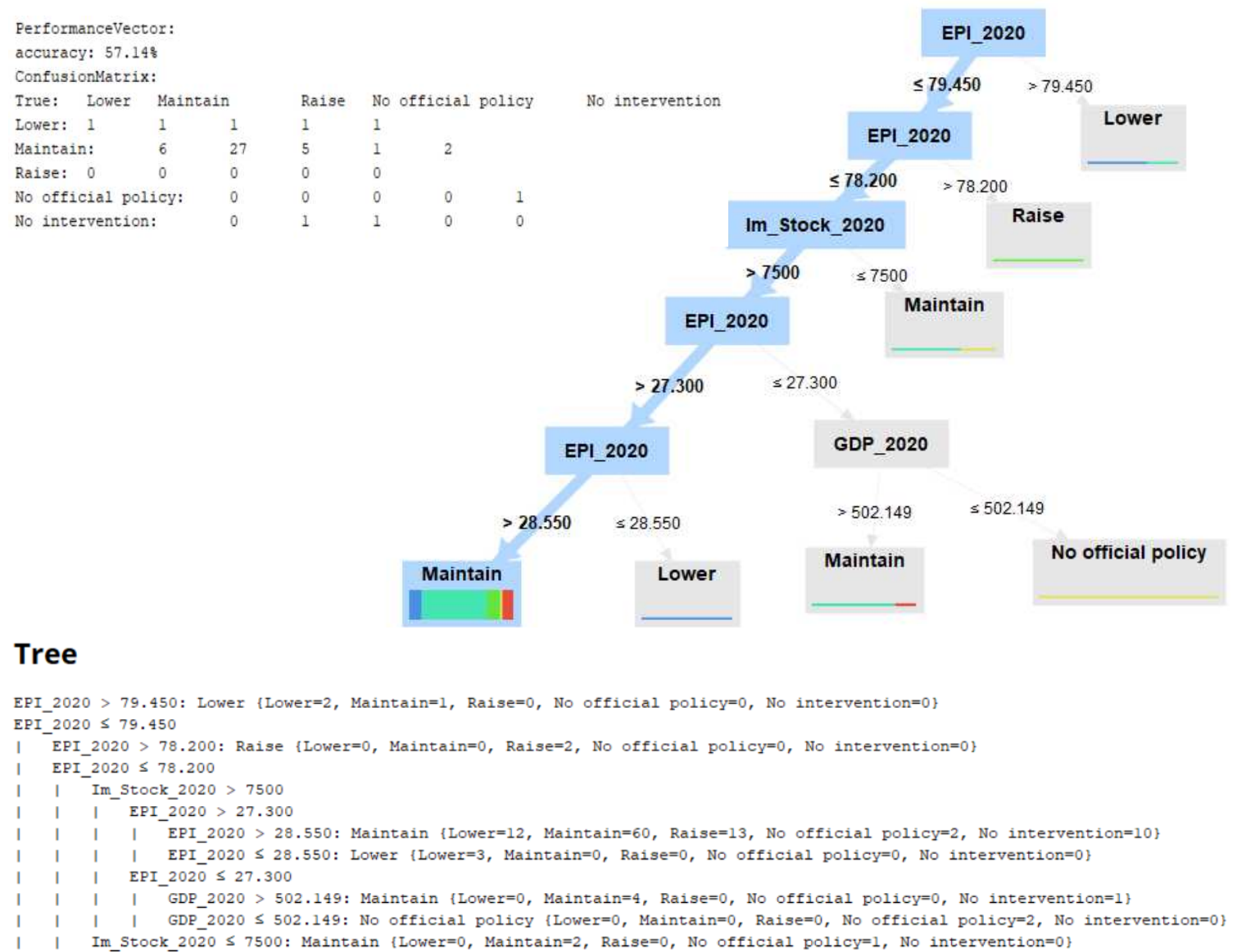

Figure 3. Decision tree for classification of policy on immigration

there are relatively few such countries: they are Denmark, Luxembourg, Switzerland, United Kingdom, France, and Austria.

In almost all other cases, the importance of such parameters as the number of immigrants in the country, as well as the level of per capita income, increases. In general, one can see the regularity of the desire of immigration policies to keep the level of immigration at the current level.

\subsection{Immigration policy on highly skilled workers}

To build a decision tree for immigration policy on highly skilled workers, a database was collected for 155 countries of the world according to the indicators indicated in Table 1. As a result of the calculations performed using the second model, the following conclusions can be drawn. First, in most countries, the immigration policy is aimed at increasing highly skilled workers (Figure 4).

Secondly, the most important among the studied indicators is the total number of immigrants in the country. When their number is minimal (less than 19,500), the country either does not have an official strategy regarding immigrants at all or is focused on maintaining the current level. However, there are few such regions, they are located mainly in Oceania, Africa, and Latin America. In other cases (when immigration stock accounts for more than 19,500), the critical value belongs to the level of the environmental performance of the country. If the value of a country's EPI is less than 26.1, it will follow the immigration policy of "maintain". Otherwise (if a country's EPI is higher than 26.1) the Education index becomes a valuable parameter. If it exceeds 0.287 , then in $51 \%$ of cases, the country's immigration policy will aim to increase 


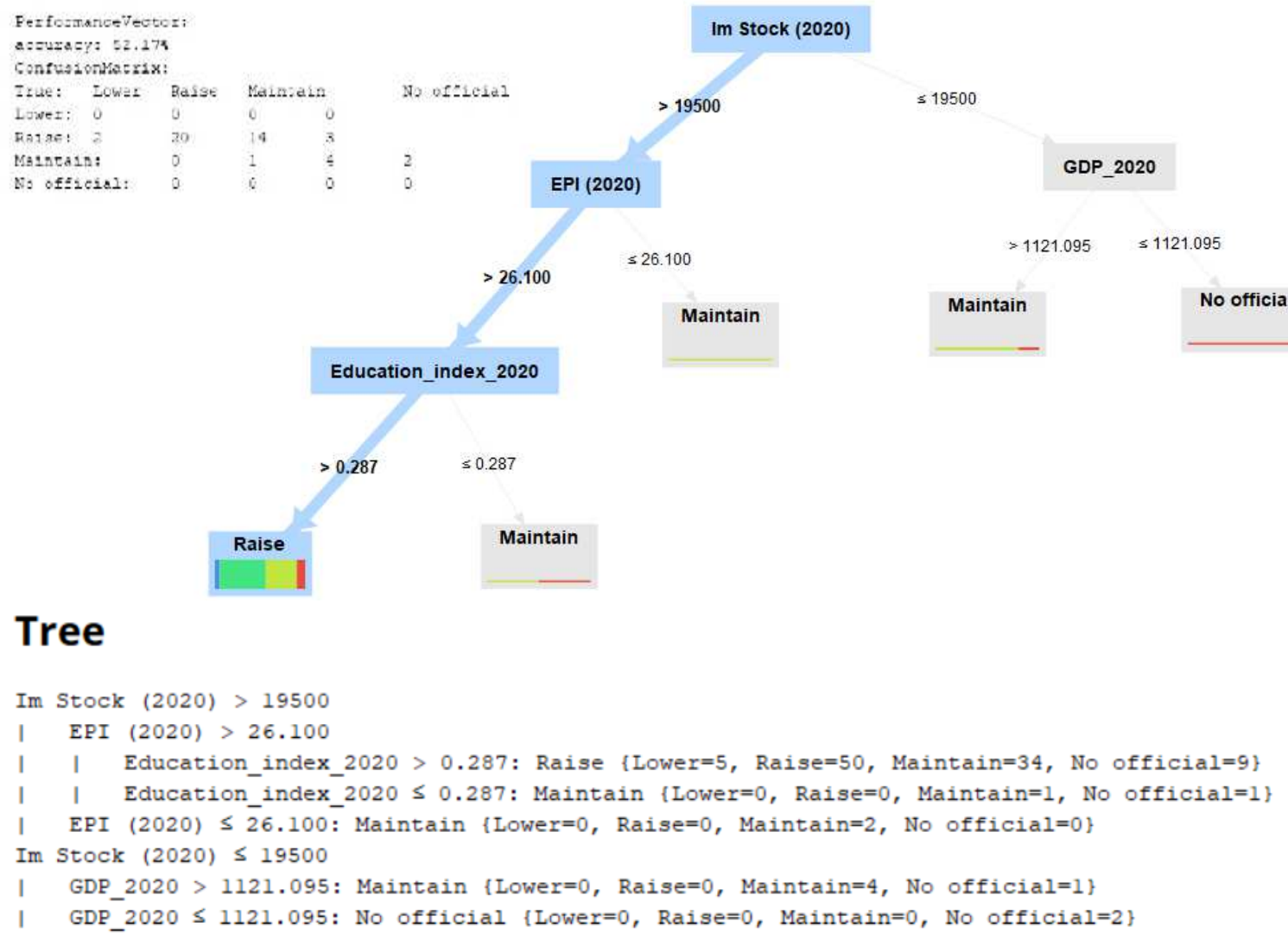

Figure 4. Decision tree for classification of immigration policy on highly skilled workers

"highly skilled workers" ("raise"). This means that countries with high immigrant populations, environmental performance, and education indicators are interested in attracting high-quality workers.

The results obtained allow making a very important observation and concluding that environmental factors are beginning to have an increasingly large influence on the immigration policy of the states. This can be explained by the grow- ing attention of the world community to climate change. The analysis of databases showed a significant difference between the level of environmental performance in Europe and Africa. Therefore, in countries with a high level of environmental efficiency, immigration policy is often focused on curbing the flow of immigrants, even highly qualified ones, since immigration flows are associated with a load on the internal ecosystem.

\section{CONCLUSION}

The relevance of the studied problem is due to the growing number of international migrants and the internationalization of the labor force, as well as the impact of rapid economic development on the environment. The dynamics of the labor movement can have a significant impact on the socio-economic and environmental conditions of the countries to which they are migrated. It is important to understand all the advantages and disadvantages of immigration to determine the most optimal policy. Migrants, of course, can pose a threat to the national economy and place a burden on the state budget, which should provide them with social support, as well as worsen the environmental situation. On the other hand, foreign specialists make up a significant part of the labor force and have the ability to ensure the competitiveness of leading enterprises. Globalization necessitates the creation and implementation of 
optimal immigration policies that will allow countries to reap the full benefits of the immigration phenomenon in the long run.

Immigration policies vary greatly from country to country but are generally divided into five main strategies: raise, maintain, lower, no interference, and no official policy (United Nations method).

The purpose of the study was to predict the immigration policies of different countries in the world by analyzing environmental performance and other influencing factors. Two predictive decision tree models developed based on the RapidMiner software package and static indicator libraries in more than 150 countries around the world allow us to draw the following conclusions.

First, in most cases, the immigration policy of the countries of the world will be aimed at maintaining the existing level of immigration and increasing the number of skilled workers.

Second, in general, countries tend to formulate immigration policies aimed at increasing the number of skilled workers. However, an important indicator is the total number of registered immigrants in the country. Therefore, if the country has very few immigrants, the government will not allocate a separate plan to attract them or try to keep them at the current level. Countries with higher immigration stock, environmental performance (EPI exceeds at least 0.26) and education index (more than 0.287 ) are interested in attracting highly skilled workers.

Third, the analysis has shown, even now the country's environmental indicators have one of the priority values in determining the state's immigration policy. Database analysis revealed significant differences between levels of environmental performance in Europe and Africa. Thus, in countries with a high degree of environmental efficiency, immigration policy often aims to limit the flow of even highly skilled immigrants, since immigration flows are associated with loads on ecosystems.

\section{AUTHOR CONTRIBUTIONS}

Conceptualization: Viktoriia Apalkova, Sergiy Tsyganov, Nataliia Meshko.

Data curation: Viktoriia Apalkova, Nadiia Tsyganova.

Formal analysis: Viktoriia Apalkova, Sergiy Tsyganov, Nataliia Meshko, Nadiia Tsyganova.

Funding acquisition: Viktoriia Apalkova, Sergiy Tsyganov, Nataliia Meshko, Nadiia Tsyganova, Serhii Apalkov.

Investigation: Viktoriia Apalkova, Nadiia Tsyganova.

Methodology: Viktoriia Apalkova, Sergiy Tsyganov, Nataliia Meshko.

Project administration: Viktoriia Apalkova, Sergiy Tsyganov.

Resources: Viktoriia Apalkova, Serhii Apalkov.

Software: Viktoriia Apalkova, Serhii Apalkov.

Supervision: Viktoriia Apalkova, Sergiy Tsyganov, Nataliia Meshko.

Validation: Viktoriia Apalkova, Nadiia Tsyganova.

Visualization: Viktoriia Apalkova, Serhii Apalkov.

Writing - original draft: Viktoriia Apalkova, Serhii Apalkov.

Writing - review \& editing: Sergiy Tsyganov.

\section{REFERENCES}

1. Adisa, O., \& McSharry, P. E. (2020). Female enrollment, child mortality and corruption are good predictors of a country's UN Education Index
(Thesis). Child Mortality and Corruption Are Good Predictors of a Country's UN Education Index Project. Retrieved from https://www.researchgate.net/ publication/342318782_Female_ enrollment_child_mortality_and_ corruption_are_good_predic- 
tors_of_a_country's_UN_Education_Index

2. Aleksynska, M., \& Tritah, A. (2015). The heterogeneity of immigrants, host countries'income and productivity: a channel accounting approach. Economic Inquiry, 53(1), 150-172. http:// dx.doi.org/10.1111/ecin.12141

3. Anderson, B. (2010). Migration, immigration controls and the fashioning of precarious workers. Work, employment and society, 24(2), 300-317. https://doi.org/10. 1177\%2F0950017010362141

4. Barnett, J. (2003). Security and climate change. Global environmental change, 13(1), 7-17. Retrieved from https://sta.uwi. edu/iir/normangirvanlibrary/sites/ default/files/normangirvanlibrary/ documents/Security\%20and\%20 Climate\%20Change.pdf

5. Bernardini, E. (2019). The highly skilled migrant in contemporary society: a conceptual analysis. Conference Proceedings of the Third International Symposium Od Diaspore Italiane, 29-33. Genova, Italy. Retrieved from https://www. diasporeitaliane.com/images/ files/20200319_Diaspore_Italiane_ conference_proceedings.pdf

6. Cangiano, A. (2012). Immigration policy and migrant labour market outcomes in the European Union: New evidence from the $E U$ Labour Force Survey (Working Paper). Retrieved from https:// labmiggov.fieri.it/wp-content/ uploads/2012/05/Cangiano-LabMig-Gov-Final-Report-WP4.pdf

7. Chandrasekar, P., Qian, K., Shahriar, H., \& Bhattacharya, P. (2017). Improving the prediction accuracy of decision tree mining with data preprocessing. 2017 IEEE 41st Annual Computer Software and Applications Conference (COMPSAC), 481-484. http://doi.org/10.1109/COMPSAC.2017.146

8. d'Albis, H., Boubtane, E., \& Coulibaly, D. (2018). Macroeconomic evidence suggests that asylum seekers are not a "burden" for Western European countries. Science advances, 4(6), eaaq0883. Retrieved from https:// www.science.org/doi/10.1126/ sciadv.aaq0883

9. Détang-Dessendre, C., Partridge, M. D., \& Piguet, V. (2016). Local labor market flexibility in a perceived low migration country: The case of French labor markets. Regional science and urban economics, 58, 89-103.

10. Dustmann, C., Hatton, T., \& Preston, I. (2005). The labour market effects of immigration. The Economic Journal, 115(507), F297-F299. Retrieved from https:// EconPapers.repec.org/RePEc:ecj :econjl:v:115:y:2005:i:507:p:f297f299

11. Feng, S., Krueger, A. B., \& Oppenheimer, M. (2010). Linkages among climate change, crop yields and Mexico-US crossborder migration. Proceedings of the national academy of sciences, 107(32), 14257-14262. https://doi. org/10.1073/pnas.1002632107

12. Friedrich-Ebert-Stiftung, Global Future, \& International Organization for Migration. (2017). Tomorrow's World of Migration. Geneva, Switzerland: FES, Global Future, IOM. Retrieved from https://www. iom.int/sites/g/files/tmzbdl486/ files/our_work/ICP/TomorrowsWorld-of-Migration-and-Mobility. pdf

13. Gabriel, C., \& Pellerin, H. (2012). Governing International Labour Migration: Current Issues, Challenges and Dilemmas. Routledge.

14. Ghimis, A. (2016). The EU's Labour Migration Policy: Recent Developments and What More is Needed. IEMed Mediterranean. Retrieved from https://www. iemed.org/publication/the-euslabour-migration-policy-recentdevelopments-and-what-more-isneeded/

15. International Organization for Migration. (2019). World Migration Report 2020. Retrieved from https://publications.iom.int/ system/files/pdf/wmr_2020.pdf
16. Johnson, I. I. (2011). Immigration as a Response Variable to Climate Change from Mexico into the United States. Journal of Alternative Perspectives in the Social Sciences, 3(3).

17. Kalra, V., \& Aggarwal, R. (2017). Importance of Text Data Preprocessing \& Implementation in RapidMiner. Proceedings of the 2017 International Conference on Information Technology and Knowledge Management, 71-75. Retrieved from https://annalscsis.org/proceedings/icitkm2017/ $\mathrm{drp} / 46 . \mathrm{html}$

18. Lacroix, T. (2012). Designing a structure/agency approach to transnationalism (Working Paper). University of Oxford. Retrieved from https://halshs.archivesouvertes.fr/halshs-00819982/file/ WP65_Designing_a_structure_ agency_approach_to_transnationalism.pdf

19. Laffineur, C., Moreno-Galbis, E., Tanguy, J., \& Tritah, A. (2017). Are immigrants' skills priced differently? Evidence from France. Retrieved from https://afse2017.sciencesconf. org/143064/Immigspecialization_January2017.pdf

20. McAuliffe, M., \& Khadria, B. (2019). Report overview: Providing perspective on migration and mobility in increasingly uncertain times (World Migration Report 2020). Retrieved from https://publications.iom.int/system/files/pdf/ wmr_2020_en_chapter1_004.pdf

21. Migration Policy Institute. (n.d.). Total Immigrant and Emigrant Populations by Country. Retrieved from https://www.migrationpolicy. org/programs/data-hub/charts/ total-immigrant-and-emigrantpopulations-country

22. Ndiaye, P. O. (2018). Migration d'étude, migration de travail: deux faces indissociables d'une même réalité? Géo-Regards, (10), 109121. (In French).

23. Patel, H. H., \& Prajapati, P. (2018). Study and analysis of decision tree based classification algorithms. International Journal of Computer Sciences and Engineering, 6(10), 74-78. http://dx.doi.org/10.26438/ ijcse/v6i10.7478 
24. Prieur, F., \& Schumacher, I. (2016). The role of conflict for optimal climate and immigration policy (TSE Working Paper 16-663). Toulouse School of Economics. Retrieved from https://ideas.repec. org/p/tse/wpaper/30519.html

25. Ries, L. (2020, October 21). President Trump and Joe Biden: Comparing Immigration Policies. The Heritage Foundation. Retrieved from https://www. heritage.org/immigration/report/ president-trump-and-joe-bidencomparing-immigration-policies

26. Stakanov, R.D. (2014).

Osoblyvosti mihratsiinoi polityky rozvynenykh krain svitu v XXI st [Peculiarities of developed countries migration policies in the twenty-first century]. Investytsii: praktyka ta dosvid - Investments: practice and experience, 15, 1115. (In Ukrainian). Retrieved from http://www.investplan.com. ua/?op=1\&z=3780\&i=1

27. Timmer, A. S., \& Williams, J. G. (1998). Immigration policy prior to the 1930s: Labor markets, policy interactions, and globalization backlash. Population and Development Review, 24(4), 739-771. https://doi. org/10.2307/2808023

28. United Nations. (2017). International Migration Policies: Data Booklet. Retrieved from https://www.un.org/en/development/desa/population/publications/pdf/policy/international_migration_policies_data_booklet.pdf

29. United Nations. (2020). Human Development Report 2020 Education Index 2020. Retrieved from http://hdr.undp.org/en/ content/2020-hdr-media-package

30. United Nations. (n.d.). Human Development Data Center.
Retrieved from http://hdr.undp. org/en/data

31. Wendling, Z. A., Emerson, J. W., de Sherbinin, A., Esty, D. C., Hoving, K., Ospina, C., Murray, J.-M., Gunn, L., Ferrato, M., Schreck, M., Jacob, M., Dahl, N., \& Gordon, A. (2020). 2020 Environmental Performance Index. New Haven, CT: Yale Center for Environmental Law \& Policy. Retrieved from https://epi. yale.edu/downloads/epi2020report20210112.pdf

32. World Bank Data. (n.d.a). GDP per capita (current US\$). Retrieved from https://databank.worldbank. org/indicator/NY.GDP.PCAP. CD/1ff4a498/Popular-Indicators

33. World Bank Data. (n.d.b). Population, total. Retrieved from https://databank.worldbank.org/ indicator/SP.POP.TOTL/1ff4a498/ Popular-Indicators 
Table A1. Data set for $1^{\text {st }}$ Model "Decision tree for classification of policy on immigration" and $2^{\text {nd }}$ Model "Decision tree for classification of policy on immigration"

\begin{tabular}{|c|c|c|c|c|c|c|c|c|c|c|}
\hline ISO & Region & Megaregion & $\begin{array}{l}\text { Policy on } \\
\text { immigration }\end{array}$ & $\begin{array}{c}\text { Policy on } \\
\text { highly skilled } \\
\text { workers }\end{array}$ & EPI (2020) & $\begin{array}{c}\text { GDP per } \\
\text { capita, } 2020\end{array}$ & $\begin{array}{l}\text { Population, } \\
\mathrm{m} \ln (2020)\end{array}$ & $\begin{array}{l}\text { Education } \\
\text { index (2020) }\end{array}$ & $\begin{array}{c}\text { Sending vs } \\
\text { Receiving } \\
(2020)\end{array}$ & $\begin{array}{c}\text { Immigration } \\
\text { Stock, mln } \\
(2020) \\
\end{array}$ \\
\hline DNK & Northern Europe & EUROPE & No official policy & Raise & 82.5 & 60909 & 5.83 & 0.92 & 2.792 & 0.718 \\
\hline LUX & Western Europe & EUROPE & Maintain & Raise & 82.3 & 38625 & 0.63 & 0.806 & 3.646 & 0.298 \\
\hline $\mathrm{CHE}$ & Western Europe & EUROPE & Lower & Maintain & 81.5 & 16082 & 8.64 & 0.9 & 3.491 & 2.491 \\
\hline GBR & Northern Europe & EUROPE & Lower & Lower & 81.3 & 40285 & 67.22 & 0.928 & 1.978 & 9.360 \\
\hline FRA & Western Europe & EUROPE & Lower & Raise & 80 & 44594 & 67.39 & 0.817 & 3.640 & 8.525 \\
\hline AUT & Western Europe & EUROPE & Raise & Raise & 79.6 & 45724 & 8.92 & 0.865 & 2.893 & 1.738 \\
\hline FIN & Northern Europe & EUROPE & Raise & Raise & 78.9 & 49041 & 5.53 & 0.927 & 1.238 & 0.386 \\
\hline SWE & Northern Europe & EUROPE & Raise & Raise & 78.7 & 51926 & 10.35 & 0.918 & 6.117 & 2.004 \\
\hline NOR & Northern Europe & EUROPE & Maintain & Raise & 77.7 & 67294 & 5.38 & 0.93 & 4.453 & 0.852 \\
\hline DEU & Western Europe & EUROPE & Raise & Raise & 77.2 & 48105 & 83.24 & 0.943 & 4.089 & 15.762 \\
\hline NLD & Western Europe & EUROPE & Maintain & Raise & 75.3 & 52304 & 17.44 & 0.914 & 2.430 & 2.358 \\
\hline JPN & Eastern Asia & ASIA & Maintain & Raise & 75.1 & 40146 & 125.84 & 0.851 & 3.426 & 2.771 \\
\hline AUS & $\begin{array}{c}\text { Australia / New } \\
\text { Zealand }\end{array}$ & OCEANIA & Maintain & Maintain & 74.9 & 51812 & 25.69 & 0.924 & 12.836 & 7.686 \\
\hline ESP & Southern Europe & EUROPE & Maintain & Raise & 74.3 & 27057 & 47.35 & 0.831 & 4.593 & 6.842 \\
\hline $\mathrm{BEL}$ & Western Europe & EUROPE & Maintain & Maintain & 73.3 & 115874 & 11.56 & 0.902 & 3.473 & 2.005 \\
\hline IRL & Northern Europe & EUROPE & Maintain & Raise & 72.8 & 83813 & 4.99 & 0.922 & 1.186 & 0.871 \\
\hline ISL & Northern Europe & EUROPE & Maintain & Raise & 72.3 & 59261 & 0.37 & 0.926 & 1.513 & 0.065 \\
\hline SVN & Southern Europe & EUROPE & Maintain & Raise & 72 & 25180 & 2.10 & 0.91 & 1.735 & 0.278 \\
\hline NZL & $\begin{array}{l}\text { Australia/New } \\
\text { Zealand }\end{array}$ & OCEANIA & Maintain & Raise & 71.3 & 41792 & 5.08 & 0.926 & 12.836 & 7.686 \\
\hline CZE & Eastern Europe & EUROPE & No official policy & No official & 71 & 22762 & 10.70 & 0.89 & 0.527 & 0.541 \\
\hline ITA & Southern Europe & EUROPE & Maintain & Raise & 71 & 31676 & 59.55 & 0.793 & 1.960 & 6.387 \\
\hline CAN & Northern America & $\begin{array}{l}\text { NORTHERN } \\
\text { AMERICA }\end{array}$ & Maintain & Maintain & 71 & 43242 & 38.01 & 0.894 & 6.229 & 8.049 \\
\hline MLT & Southern Europe & EUROPE & Maintain & Maintain & 70.7 & 27885 & 0.53 & 0.825 & 1.116 & 0.115 \\
\hline USA & Northern America & $\begin{array}{l}\text { NORTHERN } \\
\text { AMERICA }\end{array}$ & Maintain & Maintain & 69.3 & 63544 & 329.48 & 0.9 & 16.899 & 50.633 \\
\hline GRC & Southern Europe & EUROPE & Lower & Lower & 69.1 & 17676 & 10.72 & 0.849 & 1.231 & 1.340 \\
\hline SVK & Eastern Europe & EUROPE & Maintain & Raise & 68.3 & 19157 & 5.46 & 0.826 & 0.470 & 0.197 \\
\hline PRT & Southern Europe & EUROPE & Raise & Raise & 67 & 22440 & 10.31 & 0.768 & 0.481 & 1.002 \\
\hline
\end{tabular}


Table A1 (cont.). Data set for $1^{\text {st }}$ Model "Decision tree for classification of policy on immigration" and $2^{\text {nd }}$ Model "Decision tree for classification of policy on immigration"

\begin{tabular}{|c|c|c|c|c|c|c|c|c|c|c|}
\hline ISO & Region & Megaregion & $\begin{array}{l}\text { Policy on } \\
\text { immigration }\end{array}$ & $\begin{array}{c}\text { Policy on } \\
\text { highly skilled } \\
\text { workers }\end{array}$ & EPI (2020) & $\begin{array}{c}\text { GDP per } \\
\text { capita, } 2020\end{array}$ & $\begin{array}{l}\text { Population, } \\
\text { mln (2020) }\end{array}$ & $\begin{array}{l}\text { Education } \\
\text { index (2020) }\end{array}$ & $\begin{array}{l}\text { Sending vs } \\
\text { Receiving } \\
(2020)\end{array}$ & $\begin{array}{c}\text { Immigration } \\
\text { Stock, mln } \\
(2020) \\
\end{array}$ \\
\hline KOR & Eastern Asia & ASIA & Raise & Raise & 66.5 & 31489 & 51.78 & 0.865 & 0.784 & 1.728 \\
\hline ISR & Western Asia & ASIA & Raise & Maintain & 65.8 & 43611 & 9.22 & 0.883 & 5.446 & 1.954 \\
\hline EST & Northern Europe & EUROPE & Maintain & Raise & 65.3 & 23312 & 1.33 & 0.882 & 0.964 & 0.199 \\
\hline CYP & Western Asia & ASIA & Maintain & Lower & 64.8 & 26624 & 1.21 & 0.827 & 1.099 & 0.190 \\
\hline ROU & Eastern Europe & EUROPE & Raise & Raise & 64.7 & 12896 & 19.29 & 0.765 & 0.177 & 0.705 \\
\hline HUN & Eastern Europe & EUROPE & Raise & Raise & 63.7 & 15899 & 9.75 & 0.821 & 0.818 & 0.585 \\
\hline HRV & Southern Europe & EUROPE & Maintain & Raise & 63.1 & 13828 & 4.05 & 0.805 & 0.508 & 0.528 \\
\hline LTU & Northern Europe & EUROPE & Raise & Raise & 62.9 & 19998 & 2.79 & 0.898 & 0.221 & 0.145 \\
\hline LVA & Northern Europe & EUROPE & Maintain & Raise & 61.6 & 17620 & 1.90 & 0.883 & 0.630 & 0.239 \\
\hline $\mathrm{POL}$ & Eastern Europe & EUROPE & Raise & Raise & 60.9 & 15656 & 37.95 & 0.869 & 0.169 & 0.817 \\
\hline SYC & Eastern Africa & AFRICA & Lower & Maintain & 58.2 & 11425 & 0.10 & 0.726 & 0.446 & 0.013 \\
\hline SGP & South-Eastern Asia & ASIA & Maintain & Lower & 58.1 & 59798 & 5.69 & 0.844 & 7.242 & 2.524 \\
\hline$B G R$ & Eastern Europe & EUROPE & Raise & Raise & 57 & 9976 & 6.93 & 0.779 & 0.110 & 0.184 \\
\hline ARE & Western Asia & ASIA & Maintain & Raise & 55.6 & 31982 & 9.89 & 0.802 & 42.892 & 8.716 \\
\hline $\mathrm{CHL}$ & South America & $\begin{array}{l}\text { LATIN AMERICA } \\
\text { AND THE } \\
\text { CARIBBEAN }\end{array}$ & Maintain & Maintain & 55.3 & 86602 & 19.12 & 0.81 & 2.555 & 1.645 \\
\hline SRB & Southern Europe & EUROPE & Maintain & Maintain & 55.2 & 7666 & 6.91 & 0.783 & 0.820 & 0.823 \\
\hline BRN & South-Eastern Asia & ASIA & Maintain & Raise & 54.8 & 27466 & 0.44 & 0.702 & 2.469 & 0.112 \\
\hline KWT & Western Asia & ASIA & Lower & Raise & 53.6 & 22105 & 4.27 & 0.638 & 14.652 & 3.110 \\
\hline JOR & Western Asia & ASIA & Lower & Maintain & 53.4 & 4283 & 10.20 & 0.667 & 4.243 & 3.458 \\
\hline$B L R$ & Eastern Europe & EUROPE & Raise & Raise & 53 & 6411 & 9.40 & 0.838 & 0.719 & 1.067 \\
\hline $\mathrm{COL}$ & South America & $\begin{array}{l}\text { LATIN AMERICA } \\
\text { AND THE } \\
\text { CARIBBEAN }\end{array}$ & Maintain & Raise & 52.9 & 5333 & 50.88 & 0.682 & 0.630 & 1.905 \\
\hline MEX & Central America & $\begin{array}{l}\text { LATIN AMERICA } \\
\text { AND THE } \\
\text { CARIBBEAN }\end{array}$ & Maintain & Raise & 52.6 & 8347 & 128.93 & 0.703 & 0.107 & 1.198 \\
\hline CRI & Central America & $\begin{array}{l}\text { LATIN AMERICA } \\
\text { AND THE } \\
\text { CARIBBEAN }\end{array}$ & Maintain & Maintain & 52.5 & 12077 & 5.09 & 0.726 & 3.466 & 0.521 \\
\hline ARM & Western Asia & ASIA & Maintain & Maintain & 52.3 & 4267 & 2.96 & 0.74 & 0.199 & 0.190 \\
\hline
\end{tabular}


Table A1 (cont.). Data set for $1^{\text {st }}$ Model "Decision tree for classification of policy on immigration" and $2^{\text {nd }}$ Model "Decision tree for classification of policy on immigration"

\begin{tabular}{|c|c|c|c|c|c|c|c|c|c|c|}
\hline ISO & Region & Megaregion & $\begin{array}{c}\text { Policy on } \\
\text { immigration }\end{array}$ & $\begin{array}{c}\text { Policy on } \\
\text { highly skilled } \\
\text { workers }\end{array}$ & EPI (2020) & $\begin{array}{c}\text { GDP per } \\
\text { capita, } 2020\end{array}$ & $\begin{array}{l}\text { Population, } \\
\mathrm{mln}(2020)\end{array}$ & $\begin{array}{l}\text { Education } \\
\text { index (2020) }\end{array}$ & $\begin{array}{l}\text { Sending vs } \\
\text { Receiving } \\
\text { (2020) }\end{array}$ & $\begin{array}{l}\text { Immigration } \\
\text { Stock, mln } \\
(2020)\end{array}$ \\
\hline ARG & South America & $\begin{array}{l}\text { LATIN AMERICA } \\
\text { AND THE } \\
\text { CARIBBEAN }\end{array}$ & Maintain & Maintain & 52.2 & 8442 & 45.38 & 0.855 & 2.120 & 2.282 \\
\hline BRA & South America & $\begin{array}{l}\text { LATIN AMERICA } \\
\text { AND THE } \\
\text { CARIBBEAN }\end{array}$ & Raise & Raise & 51.2 & 6797 & 212.56 & 0.694 & 0.569 & 1.080 \\
\hline ECU & South America & $\begin{array}{l}\text { LATIN AMERICA } \\
\text { AND THE } \\
\text { CARIBBEAN }\end{array}$ & Lower & No & 51 & 5600 & 17.64 & 0.702 & 0.696 & 0.785 \\
\hline BHR & Western Asia & ASIA & Lower & Lower & 51 & 22402 & 1.70 & 0.769 & 16.065 & 0.936 \\
\hline RUS & Eastern Europe & EUROPE & Raise & Raise & 50.5 & 10127 & 144.10 & 0.823 & 1.082 & 11.637 \\
\hline UKR & Eastern Europe & EUROPE & Raise & Raise & 49.5 & 3727 & 44.13 & 0.799 & 0.814 & 4.997 \\
\hline URY & South America & $\begin{array}{l}\text { LATIN AMERICA } \\
\text { AND THE } \\
\text { CARIBBEAN }\end{array}$ & Raise & Raise & 49.1 & 15438 & 3.47 & 0.765 & 0.295 & 0.108 \\
\hline$A L B$ & Southern Europe & EUROPE & Maintain & Maintain & 49 & 5215 & 2.84 & 0.746 & 0.039 & 0.049 \\
\hline ATG & Caribbean & $\begin{array}{l}\text { LATIN AMERICA } \\
\text { AND THE } \\
\text { CARIBBEAN }\end{array}$ & Maintain & Maintain & 48.5 & 14450 & 0.10 & 0.665 & 0.441 & 0.029 \\
\hline VCT & Caribbean & $\begin{array}{l}\text { LATIN AMERICA } \\
\text { AND THE } \\
\text { CARIBBEAN }\end{array}$ & Maintain & Maintain & 48.4 & 7298 & 0.11 & 0.684 & 0.085 & 0.005 \\
\hline JAM & Caribbean & $\begin{array}{l}\text { LATIN AMERICA } \\
\text { AND THE } \\
\text { CARIBBEAN }\end{array}$ & Maintain & Raise & 48.2 & 4665 & 2.96 & 0.689 & 0.021 & 0.024 \\
\hline IRN & South-Central Asia & ASIA & Lower & Maintain & 48 & 2283 & 83.99 & 0.756 & 2.111 & 2.797 \\
\hline MYS & South-Eastern Asia & ASIA & Lower & Raise & 47.9 & 10402 & 32.37 & 0.726 & 1.869 & 3.477 \\
\hline TTO & Caribbean & $\begin{array}{l}\text { LATIN AMERICA } \\
\text { AND THE } \\
\text { CARIBBEAN }\end{array}$ & Maintain & Raise & 47.5 & 15384 & 1.40 & 0.728 & 0.239 & 0.079 \\
\hline PAN & Central America & $\begin{array}{l}\text { LATIN AMERICA } \\
\text { AND THE } \\
\text { CARIBBEAN }\end{array}$ & Maintain & Raise & 47.3 & 12269 & 4.31 & 0.7 & 2.245 & 0.313 \\
\hline TUN & Northern Africa & AFRICA & No intervention & No & 46.7 & 3320 & 11.82 & 0.661 & 0.067 & 0.060 \\
\hline AZE & Western Asia & ASIA & Maintain & Raise & 46.5 & 4214 & 10.11 & 0.711 & 0.217 & 0.252 \\
\hline
\end{tabular}


Table A1 (cont.). Data set for $1^{\text {st }}$ Model "Decision tree for classification of policy on immigration" and $2^{\text {nd }}$ Model "Decision tree for classification of policy on immigration"

\begin{tabular}{|c|c|c|c|c|c|c|c|c|c|c|}
\hline ISO & Region & Megaregion & $\begin{array}{l}\text { Policy on } \\
\text { immigration }\end{array}$ & $\begin{array}{c}\text { Policy on } \\
\text { highly skilled } \\
\text { workers }\end{array}$ & EPI (2020) & $\begin{array}{c}\text { GDP per } \\
\text { capita, } 2020\end{array}$ & $\begin{array}{l}\text { Population, } \\
m \ln (2020)\end{array}$ & $\begin{array}{l}\text { Education } \\
\text { index (2020) }\end{array}$ & $\begin{array}{l}\text { Sending vs } \\
\text { Receiving } \\
\text { (2020) }\end{array}$ & $\begin{array}{c}\text { Immigration } \\
\text { Stock, mln } \\
(2020)\end{array}$ \\
\hline PRY & South America & $\begin{array}{l}\text { LATIN AMERICA } \\
\text { AND THE } \\
\text { CARIBBEAN }\end{array}$ & Maintain & Raise & 46.4 & 4950 & 7.13 & 0.638 & 0.189 & 0.170 \\
\hline MNE & Southern Europe & EUROPE & Maintain & Maintain & 46.3 & 7686 & 0.62 & 0.803 & 0.534 & 0.071 \\
\hline DOM & Caribbean & $\begin{array}{l}\text { LATIN AMERICA } \\
\text { AND THE } \\
\text { CARIBBEAN }\end{array}$ & Maintain & Maintain & 46.3 & 7268 & 10.85 & 0.666 & 0.375 & 0.604 \\
\hline GAB & Middle Africa & AFRICA & Raise & Raise & 45.8 & 7006 & 2.23 & 0.65 & 8.610 & 0.417 \\
\hline BRB & Caribbean & $\begin{array}{l}\text { LATIN AMERICA } \\
\text { AND THE } \\
\text { CARIBBEAN }\end{array}$ & Lower & Raise & 45.6 & 15191 & 0.29 & 0.782 & 0.350 & 0.035 \\
\hline $\mathrm{BIH}$ & Southern Europe & EUROPE & Maintain & Maintain & 45.4 & 6032 & 3.28 & 0.711 & 0.021 & 0.036 \\
\hline LBN & Western Asia & ASIA & Maintain & Maintain & 45.4 & 4891 & 6.83 & 0.604 & 1.999 & 1.713 \\
\hline THA & South-Eastern Asia & ASIA & Raise & Raise & 45.4 & 7189 & 69.80 & 0.682 & 3.342 & 3.632 \\
\hline SUR & South America & $\begin{array}{l}\text { LATIN AMERICA } \\
\text { AND THE } \\
\text { CARIBBEAN }\end{array}$ & Maintain & Raise & 45.2 & 6491 & 0.59 & 0.675 & 0.175 & 0.048 \\
\hline MUS & Eastern Africa & AFRICA & Maintain & Raise & 45.1 & 8623 & 1.27 & 0.736 & 0.158 & 0.029 \\
\hline DZA & Northern Africa & AFRICA & Maintain & Maintain & 44.8 & 3310 & 43.85 & 0.672 & 0.124 & 0.250 \\
\hline $\mathrm{KAZ}$ & South-Central Asia & ASIA & Raise & Raise & 44.7 & 9056 & 18.75 & 0.83 & 0.888 & 3.732 \\
\hline DMA & Caribbean & $\begin{array}{l}\text { LATIN AMERICA } \\
\text { AND THE } \\
\text { CARIBBEAN }\end{array}$ & Maintain & Maintain & 44.6 & 6527 & 0.07 & 0.632 & 0.106 & 0.008 \\
\hline $\mathrm{BOL}$ & South America & $\begin{array}{l}\text { LATIN AMERICA } \\
\text { AND THE } \\
\text { CARIBBEAN }\end{array}$ & Maintain & Maintain & 44.3 & 3143 & 11.67 & 0.695 & 0.177 & 0.164 \\
\hline UZB & South-Central Asia & ASIA & Maintain & Maintain & 44.3 & 1686 & 34.23 & 0.729 & 0.573 & 1.162 \\
\hline PER & South America & $\begin{array}{l}\text { LATIN AMERICA } \\
\text { AND THE } \\
\text { CARIBBEAN }\end{array}$ & Maintain & Maintain & 44 & 6127 & 32.97 & 0.74 & 0.806 & 1.225 \\
\hline SAU & Western Asia & ASIA & Lower & Maintain & 44 & 20110 & 34.81 & 0.789 & 44.959 & 13.455 \\
\hline TKM & South-Central Asia & ASIA & Lower & & 43.9 & 7967 & 6.03 & 0.653 & 0.804 & 0.195 \\
\hline BHS & Caribbean & $\begin{array}{l}\text { LATIN AMERICA } \\
\text { AND THE } \\
\text { CARIBBEAN }\end{array}$ & Maintain & Maintain & 43.5 & 28608 & 0.39 & 0.74 & 1.182 & 0.064 \\
\hline
\end{tabular}


Table A1 (cont.). Data set for $1^{\text {st }}$ Model "Decision tree for classification of policy on immigration" and $2^{\text {nd }}$ Model "Decision tree for classification of policy on immigration"

\begin{tabular}{|c|c|c|c|c|c|c|c|c|c|c|}
\hline ISO & Region & Megaregion & $\begin{array}{c}\text { Policy on } \\
\text { immigration }\end{array}$ & $\begin{array}{c}\text { Policy on } \\
\text { highly skilled } \\
\text { workers }\end{array}$ & EPI (2020) & $\begin{array}{c}\text { GDP per } \\
\text { capita, } 2020\end{array}$ & $\begin{array}{c}\text { Population, } \\
m \ln (2020)\end{array}$ & $\begin{array}{c}\text { Education } \\
\text { index (2020) }\end{array}$ & $\begin{array}{c}\text { Sending vs } \\
\text { Receiving } \\
\text { (2020) }\end{array}$ & $\begin{array}{c}\text { Immigration } \\
\text { Stock, mln } \\
(2020)\end{array}$ \\
\hline EGY & Northern Africa & AFRICA & Lower & Maintain & 43.3 & 3548 & 102.33 & 0.618 & 0.151 & 0.544 \\
\hline GRD & Caribbean & $\begin{array}{l}\text { LATIN AMERICA } \\
\text { AND THE } \\
\text { CARIBBEAN }\end{array}$ & No official policy & No official & 43.1 & 9680 & 0.11 & 0.77 & 0.116 & 0.007 \\
\hline LCA & Caribbean & $\begin{array}{l}\text { LATIN AMERICA } \\
\text { AND THE } \\
\text { CARIBBEAN }\end{array}$ & Maintain & Maintain & 43.1 & 9276 & 0.18 & 0.672 & 0.117 & 0.008 \\
\hline SLV & Central America & $\begin{array}{l}\text { LATIN AMERICA } \\
\text { AND THE } \\
\text { CARIBBEAN }\end{array}$ & No intervention & Maintain & 43.1 & 3799 & 6.49 & 0.555 & 0.027 & 0.043 \\
\hline $\mathrm{ZAF}$ & Southern Africa & AFRICA & Maintain & Raise & 43.1 & 5091 & 59.31 & 0.724 & 3.127 & 2.860 \\
\hline TUR & Western Asia & ASIA & Maintain & Raise & 42.6 & 8538 & 84.34 & 0.731 & 1.774 & 6.053 \\
\hline MAR & Northern Africa & AFRICA & No official policy & Maintain & 42.3 & 3009 & 36.91 & 0.569 & 0.031 & 0.102 \\
\hline BLZ & Central America & $\begin{array}{l}\text { LATIN AMERICA } \\
\text { AND THE } \\
\text { CARIBBEAN }\end{array}$ & Lower & Maintain & 41.9 & 4436 & 0.40 & 0.695 & 1.176 & 0.062 \\
\hline GEO & Western Asia & ASIA & Maintain & Raise & 41.3 & 4279 & 3.71 & 0.862 & 0.092 & 0.079 \\
\hline BWA & Southern Africa & AFRICA & Maintain & Raise & 40.4 & 6711 & 2.35 & 0.676 & 1.735 & 0.110 \\
\hline NAM & Southern Africa & AFRICA & Maintain & Raise & 40.2 & 4211 & 2.54 & 0.584 & 2.290 & 0.109 \\
\hline KGZ & South-Central Asia & ASIA & Maintain & Maintain & 39.8 & 1174 & 6.59 & 0.73 & 0.257 & 0.199 \\
\hline IRQ & Western Asia & ASIA & Maintain & No official & 39.5 & 4157 & 40.22 & 0.557 & 0.176 & 0.366 \\
\hline BTN & South-Central Asia & ASIA & Maintain & Maintain & 39.3 & 3122 & 0.77 & 0.496 & 1.031 & 0.054 \\
\hline NIC & Central America & $\begin{array}{l}\text { LATIN AMERICA } \\
\text { AND THE } \\
\text { CARIBBEAN }\end{array}$ & Maintain & Maintain & 39.2 & 1905 & 6.62 & 0.573 & 0.059 & 0.042 \\
\hline LKA & South-Central Asia & ASIA & Maintain & Maintain & 39 & 3682 & 21.92 & 0.746 & 0.021 & 0.040 \\
\hline OMN & Western Asia & ASIA & Lower & Lower & 38.5 & 14216 & 5.11 & 0.718 & 94.539 & 2.373 \\
\hline $\mathrm{PHL}$ & South-Eastern Asia & ASIA & Maintain & Maintain & 38.4 & 3299 & 109.58 & 0.678 & 0.037 & 0.226 \\
\hline MWI & Eastern Africa & AFRICA & Lower & Maintain & 38.3 & 625 & 19.13 & 0.47 & 0.615 & 0.191 \\
\hline BFA & Western Africa & AFRICA & No intervention & No & 38.3 & 831 & 20.90 & 0.312 & 0.453 & 0.724 \\
\hline TJK & South-Central Asia & ASIA & Maintain & & 38.2 & 859 & 9.54 & 0.682 & 0.470 & 0.276 \\
\hline GNQ & Middle Africa & AFRICA & Maintain & Raise & 38.1 & 7143 & 1.40 & 0.467 & 1.791 & 0.231 \\
\hline
\end{tabular}


Table A1 (cont.). Data set for $1^{\text {st }}$ Model "Decision tree for classification of policy on immigration" and $2^{\text {nd }}$ Model "Decision tree for classification of policy on immigration"

\begin{tabular}{|c|c|c|c|c|c|c|c|c|c|c|}
\hline ISO & Region & Megaregion & $\begin{array}{c}\text { Policy on } \\
\text { immigration }\end{array}$ & $\begin{array}{c}\text { Policy on } \\
\text { highly skilled } \\
\text { workers }\end{array}$ & EPI (2020) & $\begin{array}{c}\text { GDP per } \\
\text { capita, } 2020\end{array}$ & $\begin{array}{c}\text { Population, } \\
m \ln (2020)\end{array}$ & $\begin{array}{c}\text { Education } \\
\text { index (2020) }\end{array}$ & $\begin{array}{c}\text { Sending vs } \\
\text { Receiving } \\
(2020) \\
\end{array}$ & $\begin{array}{c}\text { Immigration } \\
\text { Stock, mln } \\
(2020) \\
\end{array}$ \\
\hline HND & Central America & $\begin{array}{l}\text { LATIN AMERICA } \\
\text { AND THE } \\
\text { CARIBBEAN }\end{array}$ & Maintain & Maintain & 37.8 & 2406 & 9.90 & 0.499 & 0.040 & 0.039 \\
\hline IDN & South-Eastern Asia & ASIA & Maintain & Maintain & 37.8 & 3870 & 273.52 & 0.65 & 0.077 & 0.356 \\
\hline KIR & Micronesia & OCEANIA & Maintain & & 37.7 & 1671 & 0.12 & 0.594 & 0.613 & 0.003 \\
\hline WSM & Polynesia & OCEANIA & Maintain & Maintain & 37.3 & 4067 & 0.20 & 0.713 & 0.030 & 0.004 \\
\hline $\mathrm{CHN}$ & Eastern Asia & ASIA & Raise & Raise & 37.3 & 10500 & 1402.11 & 0.657 & 0.099 & 1.040 \\
\hline QAT & Western Asia & ASIA & Lower & Raise & 37.1 & 50805 & 2.88 & 0.659 & 86.605 & 2.226 \\
\hline ZWE & Eastern Africa & AFRICA & No intervention & Raise & 37 & 1128 & 14.86 & 0.587 & 0.335 & 0.416 \\
\hline CAF & Middle Africa & AFRICA & No intervention & & 36.9 & 477 & 4.83 & 0.353 & 0.108 & 0.089 \\
\hline GUY & South America & $\begin{array}{l}\text { LATIN AMERICA } \\
\text { AND THE } \\
\text { CARIBBEAN }\end{array}$ & Maintain & Raise & 35.9 & 6956 & 0.79 & 0.601 & 0.071 & 0.031 \\
\hline MDV & South-Central Asia & ASIA & Maintain & Raise & 35.6 & 7456 & 0.54 & 0.573 & 18.864 & 0.070 \\
\hline UGA & Eastern Africa & AFRICA & No intervention & No & 35.6 & 817 & 45.74 & 0.523 & 2.201 & 1.720 \\
\hline TLS & South-Eastern Asia & ASIA & Maintain & Maintain & 35.3 & 1381 & 1.32 & 0.51 & 0.212 & 0.008 \\
\hline$\angle A O$ & South-Eastern Asia & ASIA & Maintain & Raise & 34.8 & 2630 & 7.28 & 0.481 & 0.038 & 0.049 \\
\hline SDN & Northern Africa & AFRICA & Maintain & & 34.8 & 595 & 43.85 & 0.345 & 0.655 & 1.379 \\
\hline $\mathrm{ZMB}$ & Eastern Africa & AFRICA & Maintain & Maintain & 34.7 & 1051 & 18.38 & 0.557 & 0.936 & 0.188 \\
\hline KEN & Eastern Africa & AFRICA & Lower & Maintain & 34.7 & 1838 & 53.77 & 0.534 & 1.962 & 1.050 \\
\hline $\mathrm{FJI}$ & Melanesia & OCEANIA & Maintain & Maintain & 34.4 & 4882 & 0.90 & 0.764 & 0.060 & 0.014 \\
\hline ETH & Eastern Africa & AFRICA & No intervention & Raise & 34.4 & 936 & 114.96 & 0.341 & 1.147 & 1.086 \\
\hline $\mathrm{MOZ}$ & Eastern Africa & AFRICA & Maintain & Maintain & 33.9 & 449 & 31.26 & 0.395 & 0.529 & 0.339 \\
\hline RWA & Eastern Africa & AFRICA & Raise & Raise & 33.8 & 798 & 12.95 & 0.458 & 1.043 & 0.514 \\
\hline KHM & South-Eastern Asia & ASIA & Maintain & Maintain & 33.6 & 1513 & 16.72 & 0.484 & 0.072 & 0.079 \\
\hline $\mathrm{CMR}$ & Middle Africa & AFRICA & Maintain & No official policy & 33.6 & 1499 & 26.55 & 0.547 & 1.313 & 0.579 \\
\hline VNM & South-Eastern Asia & ASIA & Maintain & Raise & 33.4 & 2786 & 97.34 & 0.63 & 0.023 & 0.077 \\
\hline PAK & South-Central Asia & ASIA & Lower & Maintain & 33.1 & 1194 & 220.89 & 0.402 & 0.518 & 3.277 \\
\hline CPV & Western Africa & AFRICA & Maintain & No & 32.8 & 3064 & 0.56 & 0.562 & 0.084 & 0.016 \\
\hline NPL & South-Central Asia & ASIA & Maintain & Maintain & 32.7 & 1155 & 29.14 & 0.521 & 0.188 & 0.488 \\
\hline PNG & Melanesia & OCEANIA & Maintain & Raise & 32.4 & 2637 & 8.95 & 0.439 & 6.459 & 0.031 \\
\hline MNG & Eastern Asia & ASIA & Maintain & Raise & 32.2 & 4007 & 3.28 & 0.736 & 0.260 & 0.021 \\
\hline COM & Eastern Africa & AFRICA & No intervention & & 32.1 & 1403 & 0.87 & 0.482 & 0.083 & 0.012 \\
\hline
\end{tabular}


Table A1 (cont.). Data set for $1^{\text {st }}$ Model "Decision tree for classification of policy on immigration" and $2^{\text {nd }}$ Model "Decision tree for classification of policy on immigration"

\begin{tabular}{|c|c|c|c|c|c|c|c|c|c|c|}
\hline ISO & Region & Megaregion & $\begin{array}{c}\text { Policy on } \\
\text { immigration }\end{array}$ & $\begin{array}{c}\text { Policy on } \\
\text { highly skilled } \\
\text { workers }\end{array}$ & EPI (2020) & $\begin{array}{c}\text { GDP per } \\
\text { capita, } 2020\end{array}$ & $\begin{array}{l}\text { Population, } \\
m \ln (2020)\end{array}$ & $\begin{array}{c}\text { Education } \\
\text { index (2020) }\end{array}$ & $\begin{array}{c}\text { Sending vs } \\
\text { Receiving } \\
\text { (2020) }\end{array}$ & $\begin{array}{c}\text { Immigration } \\
\text { Stock, mln } \\
(2020)\end{array}$ \\
\hline GTM & Central America & $\begin{array}{l}\text { LATIN AMERICA } \\
\text { AND THE } \\
\text { CARIBBEAN }\end{array}$ & No intervention & Maintain & 31.8 & 4603 & 16.86 & 0.519 & 0.062 & 0.084 \\
\hline NGA & Western Africa & AFRICA & Maintain & Raise & 31 & 2097 & 206.14 & 0.499 & 0.783 & 1.309 \\
\hline NER & Western Africa & AFRICA & Maintain & Maintain & 30.8 & 565 & 24.21 & 0.249 & 0.871 & 0.348 \\
\hline SEN & Western Africa & AFRICA & No official policy & No official & 30.7 & 1488 & 16.74 & 0.345 & 0.396 & 0.275 \\
\hline BEN & Western Africa & AFRICA & No intervention & No & 30 & 1291 & 12.12 & 0.478 & 0.578 & 0.394 \\
\hline AGO & Middle Africa & AFRICA & Maintain & Raise & 29.7 & 1896 & 32.87 & 0.5 & 0.983 & 0.656 \\
\hline TGO & Western Africa & AFRICA & No intervention & No & 29.5 & 915 & 8.28 & 0.517 & 0.513 & 0.280 \\
\hline MLI & Western Africa & AFRICA & Maintain & No & 29.4 & 859 & 20.25 & 0.286 & 0.373 & 0.486 \\
\hline GNB & Western Africa & AFRICA & No intervention & No & 29.1 & 728 & 1.97 & 0.414 & 0.161 & 0.018 \\
\hline$B G D$ & South-Central Asia & ASIA & Maintain & & 29 & 1969 & 164.69 & 0.529 & 0.286 & 2.115 \\
\hline VUT & Melanesia & OCEANIA & Maintain & Maintain & 28.9 & 2783 & 0.31 & 0.561 & 0.449 & 0.003 \\
\hline DJI & Eastern Africa & AFRICA & Lower & Maintain & 28.1 & 3426 & 0.99 & 0.325 & 6.520 & 0.120 \\
\hline LSO & Southern Africa & AFRICA & No intervention & No & 28 & 861 & 2.14 & 0.532 & 0.060 & 0.012 \\
\hline GMB & Western Africa & AFRICA & Lower & Lower & 27.9 & 787 & 2.42 & 0.406 & 1.549 & 0.216 \\
\hline GHA & Western Africa & AFRICA & Lower & No & 27.6 & 2329 & 31.07 & 0.563 & 0.474 & 0.476 \\
\hline IND & South-Central Asia & ASIA & Maintain & Maintain & 27.6 & 1901 & 1380.00 & 0.555 & 0.273 & 4.879 \\
\hline HTI & Caribbean & $\begin{array}{l}\text { LATIN AMERICA } \\
\text { AND THE } \\
\text { CARIBBEAN }\end{array}$ & Maintain & & 27 & 1177 & 11.40 & 0.456 & 0.011 & 0.019 \\
\hline BDI & Eastern Africa & AFRICA & No official policy & Raise & 27 & 274 & 11.89 & 0.417 & 0.626 & 0.345 \\
\hline TCD & Middle Africa & AFRICA & Maintain & Raise & 26.7 & 614 & 16.43 & 0.288 & 2.463 & 0.547 \\
\hline MDG & Eastern Africa & AFRICA & No official policy & Maintain & 26.5 & 495 & 27.69 & 0.486 & 0.184 & 0.036 \\
\hline GIN & Western Africa & AFRICA & No intervention & No & 26.4 & 1194 & 13.13 & 0.354 & 0.220 & 0.121 \\
\hline CIV & Western Africa & AFRICA & Maintain & Maintain & 25.8 & 2326 & 26.38 & 0.453 & 2.232 & 2.565 \\
\hline SLE & Western Africa & AFRICA & No intervention & No & 25.7 & 485 & 7.98 & 0.406 & 0.352 & 0.054 \\
\hline AFG & South-Central Asia & ASIA & Maintain & Maintain & 25.5 & 509 & 38.93 & 0.414 & 0.025 & 0.144 \\
\hline MMR & South-Eastern Asia & ASIA & Maintain & Raise & 25.1 & 1400 & 54.41 & 0.464 & 0.021 & 0.076 \\
\hline LBR & Western Africa & AFRICA & Maintain & & 22.6 & 583 & 5.06 & 0.426 & 0.377 & 0.088 \\
\hline
\end{tabular}

